\title{
H. L. A. HART'S MODERATE INDETERMINACY THESIS RECONSIDERED: IN BETWEEN SCYLLA AND CHARYBDIS?*
}

\author{
Imer B. FLORES**
}

Resumen:

En este artículo el autor, en el contexto del cincuenta aniversario de $E l$ concepto del derecho de H. L. A. Hart, reconsidera la tesis de la indeterminación moderada del derecho, la cual deriva de la textura abierta del lenguaje. Para tal propósito, pretende: primero, analizar la tesis de la indeterminación moderada del derecho, i.e. determinación en los "casos fáciles" e indeterminación en los "casos difíciles", la cual recuerda la "doctrina del término medio" de Aristóteles; segundo, criticar la tesis de la indeterminación moderada del derecho por fracasar en dar lugar al término medio virtuoso entre extremos viciosos, al insistir que el ejercicio de la discreción requerida constituye una legislación "intersticial"; y, ter-

* Revised version of the papers presented in the Special Workshop "H.L.A. Hart's The Concept of Law Reconsidered" at the XXV IVR World Congress of Philosophy of Law and Social Philosophy "Law, Science, Technology", in Frankfurt am Main (Germany), August 18, 2011; and in "Congreso Internacional de Filosofia del Derecho", Coordinación del Programa de Posgrado en Derecho, Facultad de Estudios Superiores Acatlán, in Santa Cruz Acatlán, Estado de México (Mexico), November 14, 2011; and of the keynote address delivered in "Primeras Jornadas Internacionales de Filosofia del Derecho", Universidad Francisco Marroquín, Guatemala (Guatemala), November 4, 2011.

** Professor-Researcher, Instituto de Investigaciones Jurídicas (Legal Research Institute) and Facultad de Derecho (Law School), UNAM. E.mail: imer@unam.mx. I am grateful to Tom Campbell, Pierluigi Chiassoni, Noam Gur, Eerik Lagerspetz, Roger Shiner, and Ronaldo Macedo for their commentaries and reactions in the Special Workshop. I am also thankful not only to Kenneth E. Himma and Wilfrid J. Waluchow for their comments and observations but also to Juan Vega for his public remarks to the keynote address and his suggestions. All of them were extremely helpful on how to improve this version, especially Ken Himma, but errors are still mine. 
IMER B. FLORES

cero, reorganizar un argumento para una verdadera posición intermedia, la cual requiere de una forma de discreción interpretativa débil, en lugar de una forma de discreción legislativa fuerte.

Palabras clave:

Discreción, indeterminación, interpretación, legislación.

\begin{abstract}
:
In this article the author, in the context of the fiftieth anniversary of H. L. A. Hart's The Concept of Law, reconsiders the moderate indeterminacy of law thesis, which derives from the open texture of language. For that purpose, he intends: first, to analyze Hart's moderate indeterminacy thesis, i.e. determinacy in "easy cases" and indeterminacy in "hard cases", which resembles Aristotle's "doctrine of the mean"; second, to criticize his moderate indeterminacy thesis as failing to embody the virtues of a center in between the vices of the extremes, by insisting that the exercise of discretion required constitutes an "interstitial" legislation; and, third, to reorganize an argument for a truly "mean" position, which requires a form of weak interpretative discretion, instead of a strong legislative discretion.
\end{abstract}

\title{
Keywords:
}

Discretion, Indeterminacy, Interpretation, Legislation. 


\section{HART'S MODERATE INDETERMINACY THESIS RECONSIDERED}

But sailing your ship swiftly drive her past and avoid her [i.e. Charybdis], and make for Skylla's rock instead, since it is far better to mourn six friends lost out of your ship than the whole company.

Circe's advice to Odysseus, in HOMER, The Odyssey, Book XII, 108-10.

Virtue, then, is a state of character concerned with choice, lying in a mean, i.e. the mean relative to us, this being determined by a rational principle, and by that principle by which the man of practical wisdom would determine it. Now it is a mean between two vices, that which depends on excess and that which depends on defect; and again it is a mean because the vices respectively fall short of or exceed what is right in both passions and actions, while virtue both finds and chooses that which is intermediate.

ARISTOTLE, Nicomachean Ethics, Book II, Chapter VI, 1106 , 36-1107a 6 .

SUMMARY: I. Introduction. II. The Moderate Indeterminacy Thesis. III. Hart in Between... IV. Hart's Scylla and Charybdis. V. Conclusion.

\section{INTRODUCTION}

Reconsider H. L. A. Hart's legacy in the golden anniversary of The Concept of Law, ${ }^{1}$ in general, and his moderate indeterminacy of law thesis, in particular, are the principal aims of this article. Actually, Hart is considered unarguably among the jurists who contributed more to jurisprudence in the second half of the Twentieth Century, by restoring legal philosophy to a central place in the study of both law and (general) philosophy. Certainly, The Concept of Law was

1 H. L. A. Hart, The Concept of Law, Oxford: Oxford University Press, 1961 [hereinafter $C L 1$ ]. 
quintessential for that purpose and has been highly influential ever since the original publication in 1961 and subsequently with the appearance of the $2^{\text {nd }}$ edition with a "Postscript" (edited by Penelope A. Bulloch and Joseph Raz) in $1994 .^{2}$

Personally, I consider as the core contributions of Hart: (1) The concept of law as a (complex) model of rules -i.e. the union of primary and secondary rules - thesis; (2) The separation of law and morals thesis; and (3) The moderate indeterminacy of law -following the open texture of language - thesis. In what follows, I will reconsider the third thesis, but the first and second theses will be reconsidered as well. Hence, in this paper, I am assuming a conceptual methodology in which normative argument is relevant but my analysis intends to remain mostly descriptive with three main objectives: first, to analyze Hart's moderate indeterminacy thesis, i.e. determinacy in "easy cases" and indeterminacy in "hard cases", which, I argue, resembles Aristotle's "doctrine of the mean"; second, to criticize his moderate indeterminacy thesis as failing to embody the virtues of a center in between the vices of the extremes, by insisting that the exercise of discretion required constitutes an "interstitial" legislation; and, third, to reorganize an argument for a truly "mean" position, which requires a form of weak interpretative discretion, instead of a strong legislative discretion. ${ }^{3}$

2 H. L. A. Hart, The Concept of Law, 2nd. ed., Oxford: Oxford University Press, 1994 [hereinafter CL2].

3 Most of indeterminacy talk is related to language - and meaning - and can be characterized as linguistic - and semantic - indeterminacy. However, at this point, I would like to introduce a distinction between two additional kinds of indeterminacy relevant to law. On the one hand, there is epistemic indeterminacy related to uncertainty, i.e. our inability to know which the (correct) answer is to a legal dispute. On the other hand, there is systemic indeterminacy related to incompleteness, i.e. our inability to reach a (single) answer in a legal dispute, which may contingently derive from language but not necessarily reduced to it. In short, there is epistemic indeterminacy when there is no way of knowing which the (correct) answer is; and systemic indeterminacy when there is no way of reaching a (single) answer. In that sense, law may be affected by linguistic - and semanticindeterminacy and appear to have systemic indeterminacy but not necessarily if 


\section{The Moderate Indeterminacy Thesis}

Regarding the problems of legal reasoning, in general, and legal interpretation (and adjudication), in particular, ${ }^{4}$ H. L. A. Hart adopts, analogously to Hans Kelsen, a moderate version of the indeterminacy thesis, which is both epistemic and systemic. ${ }^{5}$ Let me advance, that for the Austrian jurist, such indeterminacy derives mainly from the "hierarchical structure of the legal system",6 whereas for the British legal philosopher, such indeterminacy derives mostly from the "open texture of language". ${ }^{7}$ Moreover, in my opinion, Hart's strategy additionally resembles Aristotle's "doctrine of the mean". 8

This strategy is quite explicit throughout Hart's work ${ }^{9}$ and becomes self-evident by bringing into attention both

there is a way of reaching a (single) answer transcending the linguistic - and semantic- indeterminacy. I am indebted to Ken Himma for asking me to introduce this distinction and even for proposing some labels.

4 It is worth to mention that Hart prepared the entry "Problems of the Philosophy of Law" for Paul Edward's Encyclopedia of Philosophy, which was published originally, in 1967, containing only two sets of problems: "Problems of Definition and Analysis"; and, "Problems of the Criticism of Law". But in the revised version published in his "brown book", in 1983, he included a third set, inserted in between the two original ones, namely: "Problems of Legal Reasoning". Vid. H. L. A. Hart, "Problems of the Philosophy of Law", in Essays in Jurisprudence and Philosophy, Oxford: Oxford University Press, 1983, pp. 98-109.

5 Vid. Hans Kelsen, Introduction to the Problems of Legal Theory, trans. Bonnie Litschewski Paulson and Stanley L. Paulson, Oxford: Oxford University Press, 2002, pp. 77-89 [hereinafter PTL1]; and, Pure Theory of Law, 2nd ed., trans. Max Knight, Berkeley and Los Angeles: University of California Press, 1967, pp. 349-50 [hereinafter PTL2]; and, Hart, CL1, pp. 121-50; and CL2, pp. 124-54. Vid. also Duncan Kennedy, "A Left Phenomenological Critique of the Hart/Kelsen Theory of Legal Interpretation”, in Enrique Cáceres et al., Problemas contemporáneos de la filosofía del derecho, México: Instituto de Investigaciones Jurídicas, UNAM, 2005, pp. 371-83; and a substantially revised version printed in: Legal Reasoning: Collected Essays, Aurora, Colorado: The Davies Group, 2008, pp. 153-73 [references will be made to this version].

6 Kelsen, PTL1, p. 77.

7 Hart, CL1, p. 124; and CL2, p. 128.

8 Cfr. Aristotle, "Nicomachean Ethics", in The Basic Works of Aristotle (Richard McKeon ed.), New York: Random House, 1941, Book II, Chapter VI, 1106b, 36-1107a, 6, p. 959.

9 Vid. for example, CL1, pp. 191-2; and CL2, p. 196: "But if men are not devils, neither are they angels; and the fact that they are a mean between these two ex- 
the title of chapter VII of his The Concept of Law: i.e. "Formalism and Rule-Scepticism", ${ }^{10}$ and the subtitle of his 1977 Sibley Lecture "American Jurisprudence through English Eyes": i.e. "The Nightmare and the Noble Dream", 11 both of which allow Hart to stand somewhere in a center between extremes represented not only by formalism and anti-formalism, i.e. rule-skepticism; but also by realism, i.e. nightmare (or "too bad to be remembered") and idealism, i.e. noble dream (or "too good to be true").

\section{Hans Kelsen's Frame}

Before proceeding with Hart, let me call attention to the fact that for Kelsen the "indeterminacy" derives from the "hierarchical structure of the legal system" and is labeled as (more or less) "relative" to the levels - higher or lowerof the legal system and to the movement from one level to the next. In that sense, the higher-level norm determines the process for the creation of the lower-level norm and possibly the content as well -or at least to some extent. As Kelsen acknowledges: 12

This determination, however, is never complete. The higherlevel norm cannot be binding with respect to every detail of the act putting it into practice. There must always remain a range of discretion, sometimes wider, sometimes narrower, so that the higher-level norm, in relation to the act of applying it (an act of norm creation or of pure implementation), has simply the character of a frame to be filled in by way of the act. Even a meticulously detailed command must leave a number of determinations to those carrying it out. If official

tremes is something which makes a system of mutual forbearances both necessary and possible."

10 Hart, CL1, p. 121; and CL2, p. 124.

11 H. L. A. Hart, "American Jurisprudence through English Eyes: The Nightmare and the Noble Dream", which was printed first in 11 Georgia Law Review, 969 (1977); and, later, in Essays..., supra note 4, pp. 123-44 [references will be made to this version].

12 Kelsen, PTL1, p. 78 (emphasis added). 
$A$ orders official $B$ to arrest subject $C, B$ must use his own discretion to decide when, where, and how he will carry out the warrant to arrest $C$; and these decisions depend upon external circumstances that $A$ has not foreseen and, for the most part, cannot foresee.

Additionally, Kelsen distinguishes between two kinds of "indeterminacy": "intended" and "unintended". ${ }^{13}$ According to him, the former can be part of the intention of authority issuing the higher-level norm, who decides to leave open for later settlement (by authorities responsible of determining the lower-level norms) not only the answer to the question "what" is the prescribed act but also "why" it is so; and, the latter can transcend the intention of the authority issuing the higher-level norm due to: (1) the ambiguity (or vagueness) of a word or a phrase used in expressing the norm; (2) the discrepancy, which can be total or partial, between the linguistic expression of the norm and the will of the norm-issuing authority; and (3) the contradictory existence of at least two norms purporting to be simultaneously valid and applicable to the same factual situation. ${ }^{14}$ In Kelsen's own voice: 15

In all these cases of intended or unintended indeterminacy of the lower level, various possibilities for applying the higher-level norm suggest themselves. The legal act of applying the legal norm can be made to correspond to one or another of the several possible readings of the norm. Or it can be made to correspond to the norm-issuer's will, however discovered, or to the expression he chooses. Or, in the case of the two norms contradicting each other, the legal act can be made to correspond to one or the other of them, or it can be so fashioned that decisions are taken as if norms abrogated one another. In all these cases the norm to be applied

13 Ibidem, pp. 78-80. It is worth to mention that in the English translation of the second edition of Reine Rechtslehre the word "indeterminacy" has been changed into "indefiniteness". Vid. Kelsen, PTL2, pp. 349-50.

14 Kelsen, PTL1, pp. 78-80.

15 Ibidem, p. 80 (emphasis added). 
is simply a frame within which various possibilities for application are given, and very act that stays within this frame, in some possible sense filling it in, is in conformity with the norm.

Kelsen not only advocates that the norm to be interpreted represents a frame encompassing the cognition of various possibilities for application but also challenges the "traditional jurisprudence" for its formalist inclination to "believe that, invariably, when the statute is applied in the concrete case, it can provide only one correct decision, and that the 'correctness' of this decision -its correctness in terms of the positive law - is based on the statute itself." 16 In his words: 17

From the standpoint of the positive law, however, there is no criterion on the basis of which one of the possibilities given within the frame of the norm to be applied could be favoured over the other possibilities. In terms of the positive law, there is simply no method of according to which only one of the several readings of a norm could be distinguished as 'correct' -assuming, of course, that several readings of the meaning of the norm are possible in the context of all the other norms of the statute or of the legal system. In spite of every effort, traditional jurisprudence has not yet found an objectively plausible way to settle the conflict between will and expression. Every method of interpretation developed thus far invariably leads merely to a possible result, never to a single correct result.

In short, Kelsen is right that as a matter of empirical fact within a frame there is not one but many possible applications of a norm and that the authority responsible for determining the lower-level norm is not invariably (or mechanically) in a position to reach the single one and even less that its decision is necessarily the correct one, i.e. an

16 Ibidem, p. 81.

17 Idem (emphasis added). 
epistemic indeterminacy. Nevertheless, he is apparently wrong in assuming a systemic indeterminacy, i.e. that there is never a single answer following not from the legal statute itself but from the law and the legal system as such. In my opinion, Kelsen fails to distinguish between the application of one of the various cognitive possibilities and the justification of such application as the correct one required by the law as a whole. In that sense, by pointing to the discretion of the authority to determine the lower-level norm, i.e. to choose contingently among the various possible applications one but not necessarily the correct one, he is falling not only short of the aims of a truly pure (normative) theory of law, which separates law both from fact and from morality, ${ }^{18}$ but also giving up totally a claim for "legal certainty" by labeling it an "illusion". ${ }^{19}$

At this point, let me bracket his double rejoinder that such decision: (1) is -or constitutes- an act of norm creation (or discretion in a strong sense); and (2) transforms the norm of morality, justice or so on into a norm of positive law. ${ }^{20}$ Actually, for that purpose, we turn now to Hart's account and to the question on whether he provides a better -or even successful- answer to the problems at hand.

\section{H. L. A. Hart's Core and Penumbra}

As stated before, for Hart the systemic indeterminacy - or the so-called "open texture" - of law derives from the "open texture of language". His analytical argument seems well structured and runs as follows: If all language (considered as a whole) is open textured (or has open texture) and law is expressed in (terms of) language; thus, it logically follows

18 Vid. Stanley Paulson, "Introduction", in Kelsen, PTL1, p. xxvi.

19 Kelsen, PTL1, pp. 83-4.

20 Kelsen, PTL1, pp. 82-3. 
that law is open textured (or has open texture), and as such is indeterminate (or has indeterminacy):

All language is open textured Law is expressed in language

$\therefore$ Law is open textured

In my opinion, Hart's inference is wrong: from the fact that all language (considered as a whole) is open textured (or has open texture) and law is expressed in (terms of) language; it does not follow that law is open textured (or has open texture), and as such is indeterminate (or has indeterminacy). At most, what Hart is able to demonstrate is that - since language and law are so closely interrelated- the open texture of language is present in law, but more precisely in the language in which law is expressed. Moreover, that neither does mean that law as a whole is necessarily open textured (or has open texture) nor that law is not prepared to deal with the open texture of language by appealing to something else beyond language to declare its meaning. In terms of Roberto Mangabeira Unger the latter is nothing but a form of "false necessity". 21

Let me clarify, I am neither denying that all language is open textured (or has open texture) nor that law is expressed in (terms of) language, but I am skeptical of reducing both law to (a form of) language and legal rationality to (a form of) linguistic rationality. Certainly, language is used to express propositions, in general, and propositions about law, i.e. legal propositions, in particular, but clearly law is neither identical to such propositions nor to language. From the fact that law is "identified in words" that are "verbally extricated" or "verbally formulated" 22 —explicitly and even implicitly - it neither does follow that law is (or can

21 Cfr. Roberto Mangabeira Unger, Social Theory: Its Situation and Its Task. A Critical Introduction to Politics, a Work in Constructive Social Theory, Cambridge: Cambridge University Press, 1987.

22 Hart, CL1, pp. 122-3; and CL2, pp. 125-6. 
be) exhausted by nor is (or can be) reduced to language. In that sense, being expressed in (terms of) language is a necessary but not a sufficient condition of law; and, that's why language can neither be the unique, i.e. the one and only, criteria in law nor the ultimate one. ${ }^{23}$

Anyway, we will proceed with the exam of the merits and demerits of Hart's account:

First, Hart - akin to Kelsen- arrives at the conclusion that (some degree of) indeterminacy in law is inevitable, since sometimes - or most of the time- it is necessary to leave certain issues open for later settlement, and also relative. But unlike Kelsen, Hart bases it mainly in the "open texture of language" and not in the "hierarchical structure of law". 24

Second, Hart —alike Kelsen- suggests that "the authoritative general language in which a rule is expressed may guide only in an uncertain way much as an authoritative example does" 25 and identifies "two connected handicaps": "The first handicap is our relative ignorance of fact; the second is our relative indeterminacy of aim." 26

Third, Hart -analogous to Kelsen - reaches the conclusion that some form of discretion (i.e. choice) is inevitable but, unlike the Austrian jurist, he holds that it is due to the open texture of language -and for him also of law. For that purpose, reintroduces the "No vehicles in the park" example. ${ }^{27}$ In Hart's voice: ${ }^{28}$

Faced with the question whether the rule prohibiting the use of vehicles in the park is applicable to some combination of

23 I am indebted with Ken Himma for calling me to make explicit some ideas that remained implicit in the previous paragraphs.

24 Hart, CL1, p. 124 and 128; and CL2, pp. 128 and 131.

25 Hart, CL1, p. 124; and CL2, p. 127.

26 Hart, CL1, p. 125; and CL2, p. 128 (emphasis added).

27 Hart introduces the example in his 1957 Holmes Lecture "Positivism and the Separation of Law and Morals" delivered at Harvard Law School, which was published first in 71 Harvard Law Review 593 (1958); and, later, in Essays..., supra note 4, pp. 49-87 [references will be made to this version.]

28 Hart, CL1, p. 124; and CL2, p. 127. 
circumstances in which it appears indeterminate, all that the person called upon to answer can do is to consider (as does one who makes use of a precedent) whether the present case resembles the plain case 'sufficiently' in 'relevant' respects. The discretion thus left to him by language may be very wide; so that if he applies the rule, the conclusion, even though it may not be arbitrary or irrational, is in effect a choice.

Fourth, Hart - like Kelsen- considers that (in)determinacy is a "matter of degree": law is determinate in some areas and indeterminate in others. For the Austrian jurist law is indeterminate inside the frame and determinate outside it: it is not-law at all; and for the British legal philosopher law is determinate in the core and indeterminate in the penumbra. ${ }^{29}$ In Hart's words, as originally introduced in the Holmes Lecture in 1957:30

A legal rule forbids you to take a vehicle into the public park. Plainly this forbids an automobile, but what about bicycles, roller skates, toy automobiles? What about aeroplanes? Are these, as we say, to be called 'vehicles' for the purpose of the rule or not? If we are to communicate with each other at all, and if, as in the most elementary form of law, we are to express our intentions that a certain type of behaviour be regulated by rules, then the general words we use - like 'vehicle' in the case I consider - must have some standard instance in which no doubts are felt about its application. There must be a core of settled meaning, but there will be, as well, a penumbra of debatable cases in which words are neither obviously applicable nor obviously ruled out.

And, at the end of chapter VI "The Foundations of a Legal System" of his masterpiece The Concept of Law in 1961:31

29 Vid. Kennedy, "A Left Phenomenological Critique of the Hart/Kelsen Theory of Legal Interpretation”, supra note 4, p. 154.

30 Hart, "Positivism and the Separation of Law and Morals", supra note 27, p. 63 (emphasis added).

31 Hart, CL1, pp. 119-20; and CL2, p. 123 (emphasis added). 


\begin{abstract}
All rules involve recognizing or classifying particular cases as instances of general terms, and in the case of everything which we are prepared to call a rule it is possible to distinguish clear central cases, where it certainly applies and others where there are reasons for both asserting and denying that it applies. Nothing can eliminate this duality of a core of certainty and a penumbra of doubt when we are engaged in bringing particular situations under general rules. This imparts to all rules a fringe of vagueness or 'open texture'...
\end{abstract}

Fifth, Hart - similar to Kelsen- concludes that there are at least in the peripheral cases no correct decisions or right answers and points to the authority granted to those exercising choice or discretion and their finality (not infallibility): "there is no answer which is clearly right or wrong. These can be settled only by a choice, made by someone to whose choices in this matter authority is eventually accorded." 32 On this point, keep in mind that Hart had already wisely stated not only "[I]n an ordinary game 'the score is what the scorer says it is' is not the scoring rule: it is a rule providing for the authority and finality of his application of the scoring rule in particular cases"33 but also "The scorer may make honest mistakes..."34

\title{
III. HART IN BETWEEN...
}

So far, both Hart and Kelsen agree in the claim that "indeterminacy" in law is inevitable and relative, but disagree in the reason for grounding it: indeterminacy results for the former from the "open texture of language", and for the latter from the "hierarchical structure of law". Additionally, they seem to differ regarding its implications chiefly to legal certainty. In my opinion, on the one hand, Kelsen, by calling it a mere "illusion", throws the baby out with the bath

32 Hart, CL1, p. 146; and CL2, p. 150 (emphasis added).

33 Hart, $C L 1$, p. 140; and $C L 2$, p. 144.

34 Hart, CL1, p. 139; and CL2, pp. 142-3. 
water (or even worse throws the baby out and keeps the bath water): $: 35$ interpretation of law is uncertain, i.e. epistemic indeterminacy, and more or less incomplete, i.e. systemic indeterminacy. On the other hand, Hart, by standing over the shoulders of Oliver Wendell Holmes' prediction/prophecy theory, ${ }^{36}$ defends it as a matter of degree: interpretation of law is more or less uncertain, i.e. epistemic indeterminacy, and more or less incomplete, i.e. systemic indeterminacy, depending on the open texture of language.

At the end, it is this strategy, as already advanced, which allows Hart to stand apparently somewhere in a center of virtue between extremes of vice not only (1) in between formalism and anti-formalism, i.e. rule-skepticism, and (2) in between realism, i.e. the nightmare, and idealism, i.e. the noble dream.

\section{Formalism and Anti-Formalism (i.e. Rule-Skepticism)}

On one side, Hart appears to give his dues both to formalism agreeing that there are some central -or paradigmatic - cases falling within a core of certainty or settled meaning, but disagreeing that all cases are clear and precise; and, to anti-formalism (i.e. rule-skepticism) arguing that there are other peripheral cases falling within a penumbra

35 Hart did use this expression to refer to Robert Nozick's Anarchy, State and Utopia, New York: The Free Press, 1974, vid. H. L. A. Hart, "1776-1976: Law in the Perspective of Philosophy", which was published first in 51 New York Law Review 538 (1976); and, later, in Essays..., supra note 4, pp. 145-158 [references will be made to this version.] Ibidem, p. 152: "Other theories - perhaps Professor Nozick's among them-do worse: they throw out the baby and keep the bath-water."

36 Vid. Oliver Wendell Holmes Jr., "The Path of the Law", Harvard Law Review, Vol. 10, 1897, pp. 457-78; and reprinted in Vol. 110, 1997, pp. 991-1009 [reference will be made to this version]. Ibidem, p. 993: "If you want to know the law and nothing else, you must look at it as a bad man who cares only for the material consequences which such knowledge enables him to predict, not as a good one who finds his reasons for conduct, whether inside the law or outside of it, in the vaguer sanctions of conscience." Ibidem, p. 994: "But if we take the view of our friend the bad man we shall find that he does want to know what the... courts are likely to do in fact. I am much of his mind. The prophecies of what courts will do in fact, and nothing more pretentious, are what I mean by the law." 
of doubt or unsettled meaning, but assenting that not all cases are unclear and imprecise. In that sense, he not only distinguishes between clear and envisaged cases (such as the "automobile/motor-car", the "bus", and the "motor-cycle") and unclear and unenvisaged ones (such as the "bicycle", the "roller-skates", and the "toy automobile/motor-car electrically propelled");37 but also insists in the existence of "a need for a further exercise of choice in the application of general rules to particular cases." 38

Actually, it is the abandonment of this need which constitutes the "vice" attributable to "formalism or conceptualism [which] consists in an attitude to verbally formulated rules which both seeks to disguise and to minimize the need for such choice, once the general rule has been laid down."39 Analogously, it is the mistreatment of another (equally important) need which constitutes the "vice" attributable to anti-formalism or realism -i.e. rule-skepticism: an attitude to verbally formulated rules which seeks to disclose and to maximize the need for such choice, to the extent that the general rule laid down does nothing at all, i.e. does not provide any guideline as such. 40 On the contrary, in order "[t]o escape this oscillation between extremes", Hart proposes a virtuous compromise between two social needs and suggests: ${ }^{41}$

In fact all systems, in different ways, compromise between two social needs: the need for certain rules which can, over great areas of conduct, safely be applied by private individuals to themselves without fresh official guidance or weighing up of social issues, and the need to leave open, for lat-

37 Vid. Hart, "Positivism and the Separation of Law and Morals", supra note 27, p. 63. Vid. also Hart, CL1, pp. 125-6; and CL2, p. 129.

38 Hart, CL1, p. 126; and CL2, p. 129.

39 Idem.

40 Vid. Hart, CL1, p. 133; and CL2, p. 136: "Yet 'rule-scepticism', or the claim that talk of rules is a myth, cloaking the truth that law consists simply of the decisions of courts and the prediction of them, can make a powerful appeal to a lawyer's candour."

41 Hart, CL1, p. 127; and CL2, p. 130. 
ter settlement by an informed, official choice, issues which can only be properly appreciated and settled when they arise in a concrete case.

It is clear that the "open texture of language" allows Hart to respect the first competing social need while permits him to respond to the second one by appealing to a later informed exercise of "official choice" or "discretion": "In every legal system a large and important field is left open for the exercise of discretion by courts and other officials in rendering initially vague standards determinate, in resolving the uncertainties of statutes, or in developing and qualifying rules only broadly communicated by authoritative precedents." 42

At the end, Hart considers that we face a "false dilemma":43

'Either rules are what they would be in the formalist's heaven and they bind as fetters bind; or there are no rules, only predictable decisions or patterns of behaviour.'

In that sense, he suggests: 44

Formalism and rule-scepticism are the Scylla and Charybdis of juristic theory; they are great exaggerations, salutary where they correct each other, and the truth lies between them. Much indeed that cannot be attempted here needs to be done to characterize in informative detail this middle path, and to show the varied types of reasoning which courts characteristically use in exercising the creative function left to them by the open texture of law in statute or precedent.

\section{Nightmare and Noble Dream}

On the other, Hart seems to pay his dues both to the nightmare agreeing that in some cases judges make the law which they apply to litigants, but disagreeing that they

42 Hart, CL1, pp. 132-3; and CL2, p. 136.

43 Hart, $C L 1$, p. 136; and CL2, p. 139.

44 Hart, CL1, p. 144; and CL2, p. 147. 
never declare the existing law; 45 and, to the noble dream arguing that in some cases judges do not make law and declare the existing law, but assenting that sometimes they do make (new) law and do not declare the existing law - since there is no existing law to be declared. In that sense, American Jurisprudence "has oscillated between two extremes with many intermediate stopping-places."46 Anyway, Hart acknowledges that "Litigants in law cases consider themselves entitled to have from judges an application of the existing law to their disputes, not to have new law made for them" and proceeds not only to delineate the image of the judge - following Lord Radcliffe - as an "objective, impartial, erudite, and experienced declarer of the law" but also to distinguish it from the very different image of the legislator: the maker of the law, i.e. the law-maker. ${ }^{47}$

In the nightmare view -identified with the American Legal Realism movement of 1920's and 1930's, but the characterization is equally applicable to the Critical Legal Studies movement of late-1970's and mid-1980's, and other critical theories since then-48 the distinction between the judge and the legislator is a mere illusion. The American Legal Realists - especially Jerome Frank and Karl N. Llewellynaccording to Hart "were concerned to stress the legislative opportunities of the courts" 49 and their "main effect was to convince many judges and lawyers, practical and academic, of two things": 50

45 Vid. Hart, "American Jurisprudence through English Eyes...", supra note 11, p. 127: "[In] the Nightmare view... judges make the law which they apply to litigants and are not impartial, objective declarers of existing law". Ibidem, p. 128: "[A]s if adjudication were essentially a form of law-making, never a matter of declaring the existing law".

46 Ibidem, p. 125.

47 Ibidem, p. 126 [reference is omitted].

48 Vid. v. gr. Brian Bix, Jurisprudence: Theory and Context, 3rd. ed., London: Sweet \& Maxwell, 2003, pp. 177-187, and 217-236.

49 Hart, "American Jurisprudence through English Eyes...", supra note 11, p. 131.

50 Ibidem, p. 132. 
$[F]$ irst, that they should always suspect, although not always in the end reject, any claim that existing legal rules or precedents were constraints strong and complete enough to determine what a court's decision should be without other extra-legal considerations; secondly, that judges should not seek to bootleg silently into the law their own conceptions of the law's aims or justice or social policy or other extra-legal elements required for decision, but should openly identify and discuss them.

On the contrary, in the noble dream view - represented originally by Roscoe Pound, among others, and in a more contemporary version by Ronald Dworkin - the distinction between the legislator and the judge, as well as their respective functions, i.e. law-making - ius dare- and law-declaring -ius dicere, is still quite significant. ${ }^{51}$ In that sense, Hart suggests that the noble dream: ${ }^{52}$

Like its antithesis the Nightmare, it has many variants, but in all forms it represents the belief, perhaps the faith, that, in spite even of whole periods of judicial aberrations and mistakes, still an explanation and a justification can be provided for the common expectation of litigants that judges should apply to their cases existing law and not make new law for them even when the text of particular constitutional provisions, statutes, or available precedents appears to offer no determinate guide. And with this goes the belief in the possibility of justifying many other things, such as the form of lawyer's arguments which, entertaining the same expectations, are addressed in courts to the judges as if he were looking for, not creating the law; the fact that when courts overrule some past decision, the later new decision is nor-

51 Vid. Imer B. Flores, "The Quest for Legisprudence: Constitutionalism $v$. Legalism", en Luc J. Wintgens (ed.), The Theory and Practice of Legislation: Essays on Legisprudence, Aldershot, Ashgate, 2005, pp. 46-7; "Legisprudence: The Forms and Limits of Legislation", 1 Problema. Anuario de Filosofia y Teoria del Derecho 247 (2007), pp. 257-60; and "Legisprudence: The Role and Rationality of Legislators —vis-à-vis Judges - towards the Realization of Justice”, 1:2 Mexican Law Review, 91 (2009), pp. 100-6.

52 Hart, "American Jurisprudence through English Eyes...", supra note 11, pp. 132-3. 
mally treated as stating what the law has always been, and as a correcting mistake, and is given a retrospective operation; and finally, the fact that the language of a judge's decision is not treated, as is the language of a statute, as the authoritative canonical text of a law-making verbal act.

Finally, Hart concludes: 53

I have portrayed American jurisprudence as beset by two extremes, the Nightmare and the Noble Dream: the view that judges always make and never find the law they impose on litigants, and on the opposed view that they never make it. Like any other nightmare and any other dream, these two are, in my view, illusions, though they have much of value to teach the jurist in his waking hours. The truth, perhaps unexciting, is that sometimes judges do one and sometimes the other.

\section{HART'S ScYlLA AND CHARYBDis}

Let me start this section, by recalling Hart's characterization of formalism and anti-formalism, i.e. rule-skepticism, as "the Scylla and Charybdis of juristic theory" and his insinuation that "the truth lies between them... [i.e. in the] middle path... which courts characteristically use in exercising the creative function left to them by the open texture of law in statute or precedent." 54 By the by, the depiction is equally applicable to realism (i.e. the nightmare) and to idealism (i.e. the noble dream), and his suggestion that "Like any other nightmare and any other dream, these two are... illusions, though they have much of value to teach the jurist in his waking hours. The truth, perhaps unexciting, is that sometimes judges do one and sometimes the other." 55

It is worth to mention that Scylla and Charybdis are mythical sea monsters associated with two rocks portrayed

53 Ibidem, p. 144.

54 Vid. supra note 44

55 Vid. supra note 53. 
by Homer in The Odyssey. ${ }^{56}$ The former was described as a six-headed monster with teeth set in three rows living in a cavern in the higher cliff and the latter as a monster that sucks down the water creating a whirlpool living in a fig tree dense with foliage in the lower cliff. They were regarded as a sea hazard located close enough to each other that they posed an inescapable threat to passing sailors avoiding Charybdis meant passing too close to Scylla and vice versa. In that sense, Odysseus -following Circe's advice-57 opted to pass by Scylla losing only a few sailors, rather than risking the loss of his entire ship in the whirlpool: "For you, steersman, I have this order; so store it deeply in your mind, as you control the steering oar of this hollow ship; you must keep her clear from where the smoke and the breakers are, and make hard for the sea rock lest, without your knowing, she might drift that way, and you bring all of us into disaster." 58 In the words of Aristotle: "For of the extremes one is more erroneous, one less so; therefore, since to hit the mean is hard in the extreme, we must as a second best, as people say, take the least of evils".59

My claim is that the "open texture of language" allows Hart to stand apparently somewhere in the center between extremes arguing for a moderate indeterminacy, i.e. law is sometimes determinate and sometimes indeterminate, and against both a radical determinacy, i.e. law is always determinate or never indeterminate, and radical indeterminacy, i.e. law is always indeterminate or never determinate. But by characterizing the exercise of choice or discretion - required to face the moderate indeterminacy - as legislative, Hart's position - as Odysseus- crashes into one of the extremes, i.e. Scylla, the lesser evil, failing to achieve the mid-

56 Vid. Homer, "The Odyssey", in The Iliad and the Odyssey of Homer, trans. Richmond Lattimore, Chicago: The University of Chicago and Encyclopædia Britannica, 1952, Book XII, 73-259.

57 Ibidem, 108-10.

58 Ibidem, 217-21.

59 Aristotle, "Nicomachean Ethics", supra note 8, Book II, Chapter IX, 1109a, 33-5, p. 963. 
dle path, by suggesting that in those cases judges do legislate. The problem is whether there is a truly mean position, i.e. a middle way.

In a few words, Hart affirms that a "creative judicial activity" 60 is required to face the moderate indeterminacy and certainly it implies discretion, but the problem is that he equates "creative" to "legislative" and "judicial discretion" to "judicial legislation". In Hart's voice:61

Laws require interpretation if they are to be applied to concrete cases, and once the myths which obscure the nature of the judicial processes are dispelled by realistic study, it is patent... that the open texture of law leaves a vast field for a creative activity which some call legislative. Neither in interpreting statutes nor precedents are judges confined to the alternatives of blind, arbitrary choice, or 'mechanical' deduction from rules with predetermined meaning. Very often their choice is guided by an assumption that the purpose of the rules which they are interpreting is a reasonable one, so that the rules are not intended to work injustice or offend settled moral principles... At this point judges may again make a choice which is neither arbitrary nor mechanical; and here often display characteristic judicial virtues, the special appropriateness of which to legal decision explains why some feel reluctant to call such judicial activity 'legislative'.

I accept that judges do realize a "creative judicial activity" not only by creating an individual norm to be applied to the case at hand but also by creating at the same time a criteria or precedent of interpretation that may be applied to future cases. ${ }^{62}$ However, I reject that such "creative judicial activity" amounts necessarily to a legislative one. By the

60 Hart, CL1, p. 131; and CL2, p. 134.

61 Hart, CL1, p. 200; and CL2, pp. 204-5.

62 Actually, legislatures, especially in the common law, delegate a limited authority to courts to the extent that it can be described as judge-made law through interpretation but not necessarily as judicial legislation. 
way, Hart mistakenly describes "two types of creative or legislative activity":63

On the one hand, courts deciding a later case may reach an opposite decision to that in a precedent by narrowing the rule extracted from the precedent, and admitting some exception to it not before considered, or, if considered, left open. This process of distinguishing the earlier case involves finding some legally relevant difference between it and the present case, and the class of such differences can never be exhaustively determined. On the other hand, in following an earlier precedent the courts may discard a restriction found in the rule as formulated from the earlier case, on the ground that it is not required by any rule established by statute or earlier precedent. To do this is to widen the rule.

I admit that both narrowing and widening the rule are the product of a "creative judicial activity" resulting from the interpretation of a pre-existing rule, but deny that it amounts either to the legislative creation of a (new) rule or to the quasi-legislative change of an existing rule. In both cases, i.e. narrowing and widening, there is already an existing rule, whose scope is narrowed or widened through interpretation, but the rule is neither created out-of-the-blue nor changed out-of-nothing-at-all through legislation or quasi-legislation. Similarly, I argue that in cases where there are legal gaps to be filled the judge does exercise an interpretative "creative judicial activity" in order to declare the existing law or more precisely to cover the gap with pre-existing legal material, including principles and aims or purposes. What's more, when courts overrule a previous decision, for example, Plessy $v$. Ferguson with Brown $v$. Board of Education, it seems that they are not necessarily making (new) law nor changing the existing law but recog-

63 Hart, CL1, p. 131; and CL2, p. 135 (emphasis added). 
nizing a previous mistake in interpreting the law by amending or correcting it. ${ }^{64}$

Notwithstanding, Hart' comeback in the "Postscript" regarding "judicial discretion" insists on judges having lawmaking powers and so "judicial legislation":65

[I]n any legal system there will always be certain legally unregulated cases in which on some point no decision either way is dictated by the law and the law is accordingly partly indeterminate or incomplete. If in such cases the judge is to reach a decision and is not, as Bentham once advocated, to disclaim jurisdiction or to refer the points not regulated by the existing law to the legislature to decide, he must exercise his discretion and make law for the case instead of merely applying already pre-existing settled law. So in such legally unprovided-for or unregulated cases the judge both makes new law and applies the established law which both confers and constrains his law-making powers.

And, further, suggests that such legislative powers are "interstitial": 66

It is important that the law-creating powers which I ascribe to the judge to regulate cases left partly unregulated by the law are different from those of the legislature: not only are the judge's powers subject to many constraints narrowing his choice from which a legislature may be quite free, but since the judge's power are exercised only to dispose of par-

64 Vid. supra notes 32-4 and accompanying text. I am not denying that there is a change in the state of affairs but affirming that it is corrective of a previous mistaken interpretation and as such neither legislative nor quasi-legislative, but interpretative. Consider not only Justice John Marshall Harlan's dissenting opinion in Plessy v. Ferguson but also his and Justice Oliver Wendell Holmes' dissenting opinions in Lochner $v$. New York. In both cases, the dissenting opinions: first, denounced a honest mistake in the interpretation made by the majority, which even though counted as law; and, later, became part of the prevailing interpretation within the Supreme Court, which corrected the previous interpretation. Vid. "There Is No Caste Here" and "Room for Debate and for an Honest Difference of Opinion", in Mark Tushnet (ed.), I Dissent. Great Opposing Opinions in Landmark Supreme Court Cases, Boston, Beacon Press, 2008, pp. 69-80 and 81-92.

65 Hart, CL2, p. 272 (emphasis in the original).

66 Ibidem, p. 273 (emphasis in the original). 
ticular instant cases he cannot use these to introduce large-scale reforms or new codes. So his powers are interstitial as well as subject to many substantive constraints. None the less there will be points where the existing law fails to dictate any decision as the correct one, and to decide cases where this is so the judge must exercise his law-making powers.

The part of Hart's rejoinder referring to "constraints" positions him really close to Kelsen —and even to Kennedy. ${ }^{67}$ Moreover, Hart's insistence on the nature of such law-making powers as interstitial, but legislative still, 68 gets Hart back over the shoulders of Holmes: "I recognize without hesitation that judges do and must legislate, but they can do so only interstitially; they are confined from 'molar to molecular motions'." 69 However, the fact of being interstitial does not cancel it being legislative. As you can imagine, my feeling is that Hart - by appealing to a form of discretion that equates creative to legislative- misses an important distinction and we seem to be in danger of missing too. The distinction I have in mind is between "interpretative" and "inventive" (or "legislative") "creative judicial activity", which corresponds to a "weak" and "strong" forms of discre-

67 Actually, Kennedy -in an attempt to separate himself and to some extent the Critical Legal Studies movement from the American Legal Realist movementhas insisted that the indeterminacy he has in mind is not radical since adjudication involves both freedom and constraint coming in terms both with Hart's and Kelsen's moderate indeterminacy. Vid., Kennedy, "A Left Phenomenological Critique of the Hart/Kelsen Theory of Legal Interpretation", supra note 4, pp. 153-73; "Freedom and Constraint in Adjudication: A Critical Phenomenology", 36 Journal of Legal Education 518 (1986), and reprinted in: Legal Reasoning..., supra note 4, pp. 11-85 [references will be made to this version].

68 Vid. H. L. A. Hart, "Introduction", in Essays..., supra note 4, p. 6: "[I]n any modern legal system there must be many occasions where the settled law fails to dictate a decision either way, so that if courts have to decide such cases they must exercise a limited 'interstitial' law-making power, or 'discretion'."

69 Southern Pacific v. Jensen, 244 U.S. 205, 221 (1917) (Holmes, dissenting). Vid. H. L. A. Hart, "American Jurisprudence through English Eyes..., supra note 11, p. 128 
tion, 70 i.e. between the weak discretion to interpret the (existing) law -and even implicit principles and aims or purposes - to be applied to the case at hand and the strong discretion to invent (or legislate) the (new) law -or even to change the (existing) law.

After all, Hart acknowledged: 71

[J]udges do not just push away their law books and start to legislate without further guidance from the law. Very often, in deciding such cases, they cite some general principle or some general aim or purpose which some considerable relevant area of the existing law can be understood as exemplifying or advancing and which points towards a determinate answer for the instant hard case.

Actually, reconsider Hart's "No vehicles in the park" example. Imagine that someday a boy, called Freddie, who all he wants to do is to learn how to ride his bicycle, comes into a park with it and is prevented from riding it by the park keeper, who points out to the prohibition. Suppose that his mother Mrs. Mercury challenges the decision on his behalf and reaches a point in which a judge with final authority has to settle the dispute. It is clear that the word 'vehicles' is vague but bicycles are typically included in vehicles, but it is unclear whether the prohibition incorporates bicycles or not.

What is the judge expected to do? In other words: Is the judge expected to invent (or legislate) a (new) law or to change the (existing) law, acting as a legislator? Or is expected to interpret the law, appealing not only to principles but also to aims and purposes? Alternately: Is the judge in a position to exercise a strong legislative discretion to go either way? Or is expected to exercise a weak interpretative

\footnotetext{
70 I am aware that Dworkin introduced the distinction between "weak" and "strong" forms of discretion in "The Model of Rules", but I am distancing from his use and trying to develop it in a way consistent with Hart and with a truly "mean" position. Vid. Ronald Dworkin, Taking Rights Seriously, 2nd. ed., Cambridge, Massachusetts: Harvard University Press, 1978, pp. 31-9 and 68-71.

71 Hart, CL2, p. 274.
} 
discretion to remain guided in the quest for the solution to the case at hand? In my opinion, the judge is expected to exercise a weak interpretative discretion appealing not only to principles but also to aims and purposes. In that sense, the prohibition can be said to be intended to protect the $\mathrm{u}-$ sers of the park from certain forms of vehicles that might cause a danger to them. The question is whether a boy riding a bicycle endangers the rest of the users of the park or it is compatible with them. I believe that the judge will rule that the law is that a bicycle per se does not jeopardize them and, for that reason, the prohibition "No vehicles in the park" does not apply to bicycles. ${ }^{72}$

\section{CONCLUSION}

Taking the distinction seriously implies that judges, instead of exercising a strong inventive (or legislative) discretion pushing their law books aside, instead do -and if I may add must- exercise a weak interpretative discretion by appealing not only to principles but also to aims and purposes in the quest for further guidance. The problem for Hart - and his followers - will still be that this "mean" position, i.e. creative interpretation, in between the extremes represented by non-creative interpretation, i.e. deductive or mechanical application, and creative legislation, does echoes his archenemy as Hart himself acknowledged:73

This indeed is the very nucleus if the 'constructive interpretation' which is so prominent a feature of Dworkin' theory of adjudication. But though this procedure certainly defers, it does not eliminate the moment of judicial law-making, since

72 Let me advance that the weak interpretative discretion proposed in this paper as a way of reconsidering the moderate indeterminacy of law thesis by appealing not only to principles but also to aims and purposes implies reconsidering the two other thesis identified at the outset of this paper, namely: (1) the concept of law as a (complex) model of rules; and (2) the separation of law and morals. Again, I am indebted with Ken Himma for pushing me to clear my thoughts in order to make explicit my claims and grounds for them, especially in this section.

73 Hart, CL2, pp. 274-5. 
in any hard case different principles supporting competing analogies may present themselves and a judge will often have to choose between them, relying like a conscientious legislator, on his sense of what it is best and not on any already established order of priorities prescribed for him by law. Only if for all such cases there was always to be found in the existing law some unique set of higher-order principles assigning relative weights or priorities to such competing lower-order principles, would the moment for judicial law-making be not merely deferred but eliminated. 